\title{
Pengaruh Senam Bugar Terhadap Tekanan Darah Lansia dengan Hipertensi : Studi Quasi Eksperimental
}

\section{Made Sudarma Adiputra ${ }^{1}$, Ni Luh Gede Ita Sunariati², Ni Wayan Trisnadewi ${ }^{3}$, Ni Putu Wiwik Oktaviani ${ }^{4}$}

\author{
1,4STIKES Wira Medika Bali \\ 2Dinas Kesehatan Kabupaten Badung \\ 3Program Studi Doktor Ilmu Kedokteran Universitas Udayana \\ adiputra@stikeswiramedika.ac.id ${ }^{1}$
}

\begin{abstract}
Diajukan 8 Juni 2021 Diperbaiki 14 Agustus 2021 Diterima 4 Oktober 2021
\section{ABSTRAK}

Latar Belakang: Hipertensi pada lansia merupakan peningkatan tekanan darah yang terjadi pada lanjut usia. Senam bugar merupakan aktivitas fisik dengan gerakan yang ringan dan sangat tepat bila dilakukan pada lansia hipertensi.

Tujuan: Mengetahui pengaruh senam bugar lansia terhadap tekanan darah lansia dengan hipertensi. Metode: Jenis penelitian ini adalah Quasi Experiment dengan rancangan Non-Equivalent Control Group Design. Jumlah responden yang berpartisipasi sebanyak 36 orang. Penelitian ini dibagi menjadi dua kelompok yaitu kelompok intervensi dan kelompok kontrol, pemilihan sampel diambil dengan teknik Purposive Sampling. Data dianalisis menggunakan Wilcoxon dan Mann-Whitney.

Hasil: Hasil penelitian ini menunjukkan pada kelompok perlakuan nilai rata-rata tekanan darah sistole saat pre-test 168,1 $\mathrm{mmHg}$ dan post-test 153,4 $\mathrm{mmHg}$ sedangkan diastole pre-test 95,56 $\mathrm{mmHg}$ dan post-test $82,67 \mathrm{mmHg}$, pada kelompok perlakuan secara statistik mengalami penurunan tekanan darah setelah senam bugar lansia dengan $p$-value $<0.001$ uji beda dua kelompok didapatkan hasil $p$-value $<0.001$, dari hasil ini terlihat ada perbedaan tekanan darah antara kelompok perlakuan dan kontrol.

Kesimpulan: Hal ini menunjukkan ada pengaruh yang signifikan senam bugar lansia terhadap tekanan darah lansia dengan hipertensi. Diharapkan lansia berperan aktif dalam mengikuti kegiatan senam dari posyandu lansia secara rutin untuk membantu menurunkan serta mengontrol tekanan darah tinggi.
\end{abstract}

Kata Kunci: Hipertensi; Lansia; Senam Bugar Lansia

\section{ABSTRACT}

Background: Hypertension in the elderly is an increase in blood pressure that occurs in the elderly. Gymnastics is a physical activity with light movements and is very appropriate when done in the elderly with hypertension.

Objective: This study aims to determine the effect of elderly fitness exercise on blood pressure of elderly with hypertension.

Methods: This type of research is a Quasi Experiment with a Non-Equivalent Control Group Design. Jumlah responden yang berpartisipasi sebanyak 36 orang. Penelitian ini dibagi menjadi dua kelompok yaitu kelompok intervensi dan kelompok kontrol, pemilihan sampel dilakukan dengan teknik purposive sampling. Data were analyzed using Wilcoxon and Mann-Whitney.

Results: The results of this study showed that in the treatment group the average value of systolic blood pressure at pre-test was $168.1 \mathrm{mmHg}$ and post-test was $153.4 \mathrm{mmHg}$ while diastolic pre-test was $95.56 \mathrm{mmHg}$ post-test was $82.67 \mathrm{mmHg}$, in the treatment group statistically experienced a decrease in blood pressure after elderly fitness exercise with p-value $.000(p<0.05)$, the different test of the two groups obtained p-value 0.000 , from this result it was seen that there was a difference in blood pressure between the treatment and control groups.

Conclusion: This shows that there is a significant effect of elderly fitness exercise on the blood pressure of the elderly with hypertension. It is expected that the elderly will play an active role in participating in gymnastics activities from the elderly posyandu on a regular basis to help reduce and control high blood pressure.

Keywords: Hypertension; elderly; Elderly Fitness 
PENDAHULUAN

Lanjut usia merupakan istilah bagi individu berusia diatas 60 tahun yang biasanya mengalami perubahan kumulatif, penurunan fungsi - fungsi biologis, kemunduran fisik, mental, dan sosial secara bertahap. Bertambahnya usia mengakibatkan frekuensi kejadian hipertensi meningkat (Olack et al., 2015).

Di negara berpenghasilan tinggi seperti Amerika Serikat (AS) dan Australia, populasi lansia menanggung beban hipertensi terbesar. Pada tahun 2014-2015 di Australia lansia dengan hipertensi berusia 65-74 tahun ssebanyak $44 \%$ serta berusia diatas 75 tahun sebanyak $47 \%$ yang dirawat dengan obat penurun tekanan darah serta memiliki hipertensi yang tidak terkontrol. Pada tahun 2013-2014 di Amerika Serikat jumlah lansia dengan hipertensi usia 65 tahun ke atas sebesar 32\% yang diobati dengan obat penurun tekanan darah serta memiliki tekanan darah yang tidak terkontrol (Pangaribuan \& Berawi, 2016).

Di Indonesia, Prevalensi lanjut usia pada tahun 2020 diperkirakan 10,7\% dari total penduduk. Provinsi Bali merupakan salah satu dari enam provinsi di Indonesia dengan jumlah penduduk lansia tertinggi yaitu sebesar 11,58\% (Sari et al., 2020). Disamping itu, Badung adalah salah satu kabupaten di Bali dengan penduduk lanjut usia yang tergolong tinggi, lansia dengan usia diatas 60 tahun di Kabupaten Badung pada tahun 2018 sebesar 44.436 jiwa (Dinas Kesehatan Kabupaten Badung, 2019).

Peningkatan jumlah lansia berdampak pada pembangunan kesehatan. Seiring bertambahnya usia, prevalensi hipertensi semakin meningkat dan beragam penyakit tidak menular akan bermunculan akibat penurunan fungsi fisiologis akibat proses penuaan (Abdelhafiz et al., 2018).

Hipertensi merupakan penyakit yang banyak muncul pada lansia (Eviyanti, 2020). Hipertensi ditandain dengan peningkatan abnormal pada tekanan darah secara berturut-turut. Berdasarkan kriteria WHO, tekanan darah sistol diatas $140 \mathrm{mmHg}$ dan diastole diatas $90 \mathrm{mmHg}$ dikategorikan sebagai hipertensi (Adam, 2019).

Upaya farmakologi dan nonfarmakologi merupakan upaya untuk menurunkan tekanan darah. Terapi nonfarmakologi dilakukan dengan menerapkan pola hidup sehat, mencukupi kebutuhan tidur, pikiran yang rileks, tidak mengonsumsi kafein, rokok, alkohol, dan stres, serta melakukan aktivitas fisik (olahraga) secara teratur (Eviyanti, 2020).

Olahraga yang rutin dapat menghasilkan respon yang baik pada kardiovaskuler, sehingga tekanan darah menurun dan denyut nadi istirahat menurun secara efektif. Penderita hipertensi dianjurkan untuk sering melakukan aktivitas fisik seperti senam bugar lansia karena gerakan senam ini ringan dan bisa dilakukan oleh lanjut usia (Pangaribuan \& Berawi, 2016).

Senam kebugaran dapat meningkatkan kesehatan fisik sehingga terjadi peningkatan fungsi jantung dan pembuluh darah (Choirunissa et al., 2019). Latihan yang baik untuk memperbaiki kesegaran jasmani lansia dilakukan minimal satu kali seminggu dan maksimal lima kali seminggu dengan durasi latihan 15 menit. Senam bugar lansia dapat dilakukan oleh semua lanjut usia yang tidak memiliki kecacatan fisik (Wahyuni, 2016).

Pada beberapa penelitian sebelumnya sudah dilakukan studi terkait efektivitas senam dalam menurunkan tekanan darah, akan tetapi efektivitas senam bugar dengan durasi yang panjang untuk mengatasi hipertensi pada lansia belum banyak dilakukan. Oleh sebab itu peneliti ingin melihat efektivitas senam bugar yang diberikan dalam kurun waktu 2 bulan dengan tekanan darah lansia dengan hipertensi di desa Baha wilayah kerja UPT puskesmas Mengwi I Kabupaten Badung. 
METODE

\section{Bahan dan Metode}

Penelitian ini menggunakan rancangan Quasi Experiment dengan pendekatan Non-Equivalent Control Group Design. Jumlah sampel yang berpartisipasi dalam penelitian ini adalah sebanyak 36 orang. Jumlah sampel yang berpartisipasi tersebut dibagi menjadi dua kelompok yaitu kelompok intervensi dan kelompok kontrol.

Kelompok intervensi akan diberikan senam bugar lansia sebanyak 18 orang dan kelompok kontrol tanpa perlakuan sebanyak 18 orang, pemilihan sampel tersebut diambil dengan teknik Purposive Sampling. Penelitian dilaksanakan di Desa Baha Wilayah Kerja UPT. Puskesmas Mengwi I pada tanggal 23 November 2020 sampai 23 Januari 20.

Pengumpulan data dilakukan menggunakan pedoman senam bugar lansia, lembar pengukuran tekanan darah dan alat sphygmomanometer digital yang telah dikalibrasi. Teknik analisis yang digunakan Wilcoxon dan Mann-Whitney. Penelitian ini dinyatakan baik etik oleh Komisi Etik Penelitian Kesehatan (KEPK) Politeknik Kesehatan Denpasar No.LB.02.03EA/KEPK/ 0333/2020

\section{Prosedur Eksperimen}

Kelompok perlakuan diberikan senam bugar lansia, sedangkan kelompok kontrol tanpa perlakuan tidak dilakukan intervensi. Sebelum intervensi pertama kali pada lansia akan dilakukan pengukuran tekanan darah (pre-test). Kemudian akan dilanjutkan senam bugar lansia 20 menit. Intervensi atau perlakuan ini dilakukan dua kali dalam seminggu selama dua bulan berturut-turut.

Setelah intervensi selesai, dilakukan pengukuran tekanan darah kembali (posttest). Pengukuran pre-test dan post-test dilakukan masing-masing satu kali. Pengukuran pre-test dilakukan 10 menit sebelum intervensi pertama dilakukan, sedangkan pengukuran post-test dilakukan

30 menit setelah intervensi terakhir selesai.

\section{HASIL DAN PEMBAHASAN}

Hasil

Tabel 1. Karakteristik Responden

\begin{tabular}{|c|c|c|c|c|c|}
\hline \multirow{2}{*}{ No } & \multirow{2}{*}{ No } & \multicolumn{2}{|c|}{ Perlakuan } & \multicolumn{2}{|c|}{ Kontrol } \\
\hline & & $F$ & $\%$ & f & $\%$ \\
\hline \multirow[t]{3}{*}{1.} & Usia (Tahun) & & & & \\
\hline & a. $60-70$ tahun & 11 & 61,11 & 12 & 66,67 \\
\hline & b. $71-80$ tahun & 7 & 38,99 & 6 & 33,33 \\
\hline \multirow[t]{2}{*}{2.} & Jenis Kelamin & & & & \\
\hline & a. Laki-laki & 11 & 61,11 & 6 & 33,33 \\
\hline & $\begin{array}{l}\text { b. Perempuan } \\
\text { Pendidikan }\end{array}$ & 7 & 38,89 & 12 & 66,67 \\
\hline \multirow{3}{*}{3.} & a. Tidak Sekolah & 6 & 33,33 & 9 & 50 \\
\hline & b. SD & 11 & 61,11 & 9 & 50 \\
\hline & c. Perguruan Tinggi & 1 & 5,56 & 0 & 0 \\
\hline \multirow[t]{7}{*}{4.} & Pekerjaan & & & & \\
\hline & a. Tidak bekerja & 12 & 66,67 & 8 & 44,44 \\
\hline & b. IRT & 0 & 0 & 3 & 16,67 \\
\hline & c. Pedagang & 0 & 0 & 3 & 16,67 \\
\hline & d. Petani & 3 & 16,67 & 4 & 22,22 \\
\hline & e. Buruh & 2 & 11,11 & 0 & 0 \\
\hline & f. Pensiunan & 1 & 5,55 & 0 & 0 \\
\hline
\end{tabular}

Tabel 1 terlihat karakteristik responden dari kelompok usia didominasi 60-70 tahun baik pada kelompok kasus $61,11 \%$ maupun kontrol 66,67\%. Karakteristik berdasarkan jenis kelamin, kelompok perlakuan didominasi laki-laki dan kelompok kontrol perempuan.

Tabel 2. Tekanan darah rata-rata pada masing-masing kelompok

\begin{tabular}{lllccc}
\hline No & Kelompok & \multicolumn{1}{c}{ Test } & Min & Max & Mean \\
\hline 1. Perlakuan & & & & \\
& a. Sistolik & Pre-test & 152 & 197 & 168,1 \\
& Post-test & 145 & 170 & 153,4 \\
& b. Diastolik & Pre-test & 90 & 121 & 95,56 \\
& & Post-test & 68 & 90 & 82,67 \\
& & & & \\
2. Kontrol & & & & \\
& a. Sistolik & Pre-test & 150 & 197 & 167.33 \\
& Post-test & 147 & 195 & 166.38 \\
& b. Diastolik & Pre-test & 89 & 105 & 94.44 \\
& Post-test & 86 & 103 & 93.61 \\
\hline
\end{tabular}

Table 2 menunjukkan pada kelompok perlakuan tekanan darah sistol rata-rata pretest $168,1 \mathrm{mmHg}$, sedangkan tekanan darah diastol rata-rata pretest 95,56 mmHg. Rata-rata tekanan darah sistol pada pretest $167 \mathrm{mmHg}$ dan diastole 94,44 $\mathrm{mmHg}$. 
Pengaruh Senam Bugar Terhadap Tekanan Darah Lansia dengan...

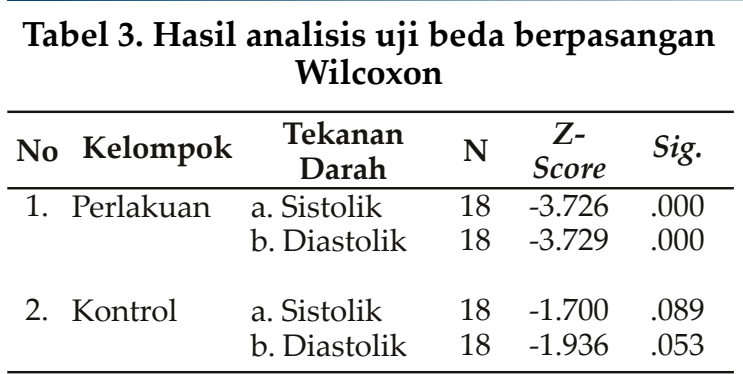

Pada tabel 3 disajikan data hasil analisis statistik menggunakan uji beda berpasangan (Wilcoxon). pada kelompok perlakuan terlihat hasil yang signifikan sebelum dan setelah diberikan perlakuan dengan p-value 0.000 , sedangkan pada kelompok kontrol tidak terdapat perbedaan pre-post baik tekanan darah sistol maupun diastole.

Tabel 4. Hasil uji beda dua kelompok tidak berpasangan

\begin{tabular}{clccc}
\hline \multirow{2}{*}{ No } & \multicolumn{3}{c}{ Uji Mann-Whitney } \\
\cline { 2 - 4 } Indikator & N & Z-Score & Sig. \\
\hline 1. & $\begin{array}{l}\text { a. Tekanan Darah Sistole } \\
\text { b. Perlakuan dengan }\end{array}$ & 36 & -5.038 & .000 \\
$\begin{array}{l}\text { Kontrol } \\
\text { a. Tekanan Darah }\end{array}$ & 36 & -4.963 & .000 \\
$\begin{array}{l}\text { Diastole } \\
\text { b. Perlakuan dengan }\end{array}$ & & & \\
Kontrol & & & \\
\hline
\end{tabular}

Tabel 4 menunjukkan hasil uji beda berpasangan tekanan dara sistol dan diastol antara kelompok kontrol dengan perlakuan, dimana $\mathrm{p}$-value pada sistol dan diastole 0.000 yang berarti terdapat perbedaan tekanan darah pada kelompok perlakuan dengan kontrol.

\section{Pembahasan}

Tabel 2 menunjukkan tekanan darah rata-rata kelompok perlakuan sebelum senam bugar sistole 168,1 $\mathrm{mmHg}$ dan diastole $95,56 \mathrm{mmHg}$, sedangkan pada kelompok kontrol sistol $167.33 \mathrm{mmHg}$ dan diastole $94.44 \mathrm{mmHg}$. Hasil tersebut menunjukkan tekanan darah lanjut usia masih tergolong tinggi.

Sesuai dengan penelitian Ramadhanti and Oktavia (2020), didapatkan data bahwa sebelum intervensi rata-rata tekanan darah sistole $156,17 \mathrm{mmHg}$ dan 92,30 $\mathrm{mmHg}$ tekanan darah diastole.
Seiring bertambahnya usia keelastisan arterial dan arteriolar akan mengalami perubahan sehingga terjadi peningkatan tekanan darah (Olack et al., 2015). Faktor yang mempengaruhi hipertensi pada responden yaitu usia, jenis kelamin, sosial ekonomi, tingkat pendidikan dan aktivitas fisik (Olack et al., 2015).

Faktor usia dapat mempengaruhi tekanan darah (Riamah, 2019). Mayoritas rentang usia pada kelompok perlakuan dan kontrol yaitu 60-70 tahun yang mana tekanan darah penderita statis pada awal pengukuran sampai akhir pengukuran. Lansia dengan usia 60-64 tahun 2,18 kali mengalami peningkatan risiko hipertensi, 2,45 kali pada usia 65-69 tahun dan 2,97 kali pada usia > 70 tahun (Riamah, 2019). Peningkatan terjadi karena hilangnya kelenturan dan kekakuan pada arteri besar sehingga darah mengalir dengan terpaksa saat jantung memompanya dan hal tersebut mengakibatkan meningkatnya tekanan darah (Mulyadi et al., 2019).

Secara tidak langsung tingkat pendidikan dapat mempengaruhi tekanan darah. Mayoritas pendidikan terakhir subyek penelitian adalah SD (Sekolah Dasar). Penyakit hipertensi meningkat dan menurun sesuai dengan tingkat pendidikan, hal tersebut dipengaruhi oleh pengetahuan pola hidup sehat penderita misalnya olahraga yang tidak teratur (Suaib, 2019).

Penyebab mayoritas subyek penelitian ini tidak bekerja adalah faktor usia yang memasuki masa purna tugas, sehingga seseorang akan beraktivitas fisik secara aktif saat bekerja dan hal tersebut bisa mempengaruhi tekanan darah. Jika, kurang beraktivitas maka akan mempengaruhi kerja jantung sehingga kerja jantung lebih keras saat berkontraksi (Wulandari \& Marliana, 2019).

Berdasarkan Tabel 2 terlihat bahwa rata-rata tekanan darah setelah diberikan intervensi senam bugar pada kelompok perlakuan adalah sistolik 153,4 $\mathrm{mmHg}$ dan diastole $82,67 \mathrm{mmHg}$, sedangkan pada 
kelompok kontrol sistol $166.38 \mathrm{mmHg}$ dan diastole $93.61 \mathrm{mmHg}$. Hasil ini menunjukkan ada perubahan tekanan darah lansia setelah diberikan intervensi terutama pada kelompok perlakuan. Penelitian ini sesuai dengan Wulandari (2019), didapatkan bahwa hasil post-test sistole dan diastole diperoleh rata-rata $124,66 \mathrm{mmHg}$ dan $81,66 \mathrm{mmHg}$. Hal ini berarti menurunnya tekanan darah setelah senam bugar lansia.

Aktivitas fisik tersebut sedang mempunyai peranan terhadap penurunan tekanan darah pada penderita hipertensi (Olack et al., 2015). Hal ini karena terjadinya vasodilatasi pembuluh darah yang mengakibatkan meningkatnya aliran darah ke sel dan jaringan sehingga saat berolahraga senam lansia kerja saraf simpatis dan parasimpatis dirangsang dan menyebabkan menurunnya tekanan darah (Fernalia et al., 2021).

Pada kelompok perlakuan tekanan darah sistole setelah dilakukan senam bugar lansia masih dikategori hipertensi, namun sudah terjadi penurunan dari sebelumnya, penurunan yang tidak signifikan mungkin dipengaruhi oleh usia dari responden. Semakin bertambahnya usia maka kelenturan pembuluh darah tepi menjadi menurun yang mengakibatkan tahanan pembuluh darah perifer lebih tinggi sehingga tekanan darah meningkat (Riamah, 2019).

Meningkatnya usia juga meningkatkan tekanan darah sistolik. Hal ini terjadi karena kekakuan katup jantung dan penebalan pada sistem kardiovaskuler. Menurunnya kelenturan pembuluh darah, kontraksi dan volume darah akibat menurunnya kekuatan jantung dalam memompa darah yang menyebabkan tekanan darah meningkat (Mulyadi et al., 2019).

Penatalaksanaan non-farmakologi secara teratur dapat menjaga tekanan darah pada penderita hipertensi (Hikayati, 2014). Terapi non-farmakologi seperti olahraga dapat mengontrol tekanan darah, olahraga yang sesuai bagi lansia yaitu senam bugar lansia (Upriani \& Priyantari, 2018).

Manfaat senam bagi lansia yaitu menjadikan peredaran darah lancar, aktivitas metabolisme tubuh serta kebutuhan oksigen meningkat. Senam akan memberikan efek berupa relaksasi yang disebabkan oleh adanya pelepasan hormone endhorphine oleh tubuh sehingga sistem saraf otonom mengendalikan tekanan darah secara refleks (Novita Indra, 2015). Senam bugar lansia ialah gerakan senam yang sesuai dengan karakteristik dan kebutuhan gerak bagi lansia (Upriani \& Priyantari, 2018).

Hasil analisis Wilcoxon dan MannWhitney diperoleh $\mathrm{p}$-value $0,000(\mathrm{p}<0,05)$ berarti ada pengaruh yang bermakna senam bugar lansia dengan perubahan tekanan darah sistole dan diastol lansia dengan hipertensi di Desa Baha Wilayah Kerja UPT. Puskesmas Mengwi I.

Penelitian Ramadhanti and Oktavia, (2020) mengungkapkan bahwa ada pengaruh yang bermakna dilakukannya senam kebugaran lansia terhadap tekanan darah lansia dengan hipertensi dengan $\mathrm{p}$ value $0,000<0,05$ pada tekanan darah sistole dan diastole. Olahraga yang teratur akan menurunkan tekanan darah dan mempunyai efek antioksidan bagi tubuh (Ruangthai \& Phoemsapthawee, 2019).

Apabila seseorang melakukan latihan fisik atau olahraga teratur, maka akan menurunkan risiko terjadinya hipertensi (Faselis et al., 2012). Olahraga teratur juga dapat menurunkan risiko kematian pada penderita hipertensi (Kokkinos et al., 2014).

Hasil yang mendukung juga didapat pada penelitian Choirunissa et al., (2019), mengungkapkan adanya pengaruh senam kebugaran terhadap penurunan tekanan darah lansia dengan hipertensi dengan $\mathrm{p}$ value $<0,001$ pada tekanan darah sistole dan p-value 0,008 pada tekanan darah diastole. Sejalan dengan penelitian Asnuddin (2017), yang mengungkapkan terdapat pengaruh senam lansia terhadap 
penurunan tekanan darah lansia dengan p-value $<0,001$.

Kebugaran fisik ditingkatkan melalui olahraga. Manfaat dari olahraga yaitu memperlancar peredaran darah sehingga terjadi penurunan tekanan darah, meningkatkan kekuatan otot, menurunkan kolesterol jahat dan meningkatkan kolesterol baik, keseimbangan, koordinasi otot serta imunitas (Upriani \& Priyantari, 2018).

Salah satu olahraga yang efektif untuk lansia adalah senam bugar lansia karena seiring bertambahnya usia kinerja mesin pemompa jantung menurun sehingga terjadi kekakuan pembuluh darah di jantung dan otak. Kekuatan pompa jantung meningkat dengan melakukan senam secara rutin. Hal tersebut akan berdampak baik pada tekanan darah lansia (Wulandari \& Marliana, 2019).

Olahraga secara rutin dapat menghasilkan hormon endorfin yang berdampak pada munculnya rasa nyaman dan bahagia (Fernalia et al., 2021). Olahraga juga mempengaruhi mekanisme HPA (Hipotalamus Hipofisis Adrenal) sehingga menghasilkan kelenjar pineal yang mengeluarkan melatonin serta serotonin. Stimulasi ditularkan dari hipotalamus ke kelenjar pituitari menghasilkan beta-endorfin dan enkefalin, yang menimbulkan relaksasi dan perasaan senang.

Senam bugar lansia bermanfaat untuk meningkatkan kesegaran jasmani yang optimal untuk orang dengan tekanan darah tinggi. Senam secara teratur dapat meningkatkan kebugaran jasmani, sehingga penderita merasa bugar dan tidak terlalu cemas, timbul perasaan gembira sehingga kualitas hidup meningkat.

Kelemahan dalam penelitian ini peneliti tidak mengontrol jenis kelamin yang merupakan salah satu faktor perancu, akan tetapi efek dari variabel perancu ini dapat diminimalkan dengan rancangan Quasi-Eksperimen yang digunakan dalam penelitian ini.

\section{KESIMPULAN}

Olahraga senam bugar lansia yang diberikan pada kelompok perlakuan memiliki pengaruh yang signifikan pada penurunan tekanan darah sistole dan diastol. Oleh Karena itu hal ini penting di informasikan bagi para lansia, bahwa senam bugar dapat dijadikan alternatif solusi dalam penanganan hipertensi selain terapi obat-obatan.

\section{UCAPAN TERIMAKASIH}

Penulis mengucapkan terima kasih banyak kepada Dinas Kesehatan Kabupaten Badung dan UPT Puskesmas Mengwi 1 yang sudah memberikan ijin dalam pengambilan data dan penelitian.

\section{DAFTAR PUSTAKA}

Abdelhafiz, A. H., Marshall, R., Kavanagh, J., \& El-Nahas, M. (2018). Management of hypertension in older people. Expert Review of Endocrinology $\mathcal{E}$ Metabolism, 13(4), 181-191. https:// doi.org/ 10.1080/17446651.2018.1500893

Adam, L. (2019). Determinan Hipertensi pada Lanjut Usia. Jambura Health and Sport Journal, 1(2), 82-89.

Asnuddin. (2017). Pengaruh Senam Lansia Terhadap Penurunan Tekanan Darah Pada Lansia yang Mengalami Hipertensi. Ilmiah Kesehatan, 6(1), 6569.

Choirunissa, R., Suprihatin, \& Prastika, G. U. (2019). Pengaruh Senam Kebugaran Terhadap Tekanan Darah Pada Lansia Penderita Hipertensi Di Puskesmas Tambah Subur Kecamatan Way Bungur Provinsi Lampung Tahun 2019. Jurnal Ilmu Dan Budaya, 41(66), 7825-7834.

Dinas Kesehatan Kabupaten Badung. (2019). Profil Kesehatan Dinas kesehatan Kabupaten Badung 2018.

Eviyanti. (2020). Pengaruh Senam Lansia Terhadap Penurunan Tekanan Darah 
Di PSTW Sleman Yogyakarta 2020. Junal Kesehatan Luwu Raya, 7(1), 82-87.

Faselis, C., Doumas, M., Kokkinos, J. P., Panagiotakos, D., Kheirbek, R., Sheriff, H. M., Hare, K., Papademetriou, V., Fletcher, R., \& Kokkinos, P. (2012). Exercise capacity and progression from prehypertension to hypertension. Hypertension, 60(2), 333$338 . \quad$ https://doi.org/10.1161/ HYPERTENSIONAHA.112.196493

Fernalia, F., Listiana, D., \& Monica, H. (2021). Pengaruh Senam Ergonomik Terhadap Tekanan Darah Pada Pasien Dengan Hipertensi Di Wilayah Kerja Puskesmas Bentiring Kota Bengkulu. Malahayati Nursing Journal, 3(1), 1-10. https://doi.org/10.33024/

manuju.v3i1.3576

Hikayati, H. (2014). Penatalaksanaan Non Farmakologis Terapi Komplementer Sebagai Upaya Untuk Mengatasi Dan Mencegah Komplikasi Pada Penderita Hipertensi Primer Di Kelurahan Indralaya Mulya Kabupaten Ogan Ilir. Jurnal Pengabdian Sriwijaya, 2(2), 124131. https://doi.org/10.37061/ jps.v2i2.1605

Kokkinos, P., Faselis, C., Myers, J., Kokkinos, J. P., Doumas, M., Pittaras, A., Kheirbek, R., Manolis, A., Panagiotakos, D., Papademetriou, V., \& Fletcher, R. (2014). Statin therapy, fitness, and mortality risk in middleaged hypertensive male veterans. American Journal of Hypertension, 27(3), 422-430. https://doi.org/10.1093/ajh/ hpt241

Mulyadi, A., Sepdianto, T. C., \& Hernanto, D. (2019). Gambaran Perubahan Tekanan Darah Pada Lansia Hipertensi Yang Melakukan Senam Lansia. Journal of Borneo Holistic Health, 2(2), 148-57.

Novita Indra, E. (2015). Pengaturan Tekanan Darah Jangkapendek, Jangka Menengah,Dan Jangka Panjang. Medikora, 2, 185-200. https://doi.org/ 10.21831/medikora.v0i2.4677
Olack, B., Wabwire-Mangen, F., Smeeth, L., Montgomery, J. M., Kiwanuka, N., \& Breiman, R. F. (2015). Risk factors of hypertension among adults aged 3564 years living in an urban slum Nairobi, Kenya. BMC Public Health, 15(1), 1251. https://doi.org/10.1186/ s12889-015-2610-8

Pangaribuan, B. B. P., \& Berawi, K. (2016). Pengaruh SenamJantung, Yoga, Senam Lansia,dan Senam Aerobik dalam Penurunan Tekanan Darah pada Lanjut Usia. Majority, 5(4), 1-6.

Ramadhanti, A., \& Oktavia, N. A. (2020). Pengaruh Senam Kebugaran Lansia Terhadap Penurunan. Dewi Rinta, 3(2), 60-67.

Riamah. (2019). Faktor-Faktor Penyebab Terjadinya Hipertensi Pada Lansia Di UPT PTSW Khusnul Khotimah. Menara Ilmu, XIII(5), 106-113.

Ruangthai, R., \& Phoemsapthawee, J. (2019). Combined exercise training improves blood pressure and antioxidant capacity in elderly individuals with hypertension. Journal of Exercise Science E Fitness, 17(2), 67$76 . \quad$ https://doi.org/10.1016/ j.jesf.2019.03.001

Sari, N. R., Maylasari, I., Dewi, F. W. R., Putrianti, R., Nugroho, S. W., \& Wilson, H. (2020). Statistik Penduduk Lanjut Usia 2020. Badan Pusat Statistik.

Suaib, M. (2019). Hubungan Tingkat Pengetahuan Dengan Kejadian Hipertensi Pada Lansia. Jurnal Fenomena Kesehatan, 2(1), 269-276.

Upriani, \& Priyantari, W. (2018). Pengaruh Senam Ergonomic Terhadap Tekanan Darah Pada Lansia Di Panti Wredha Budhi Dharma Yogyakarta. Jurnal Kesehatan Madani Medika, 9(2), 98-104. https://doi.org/10.36569/jmm.v9i2.16

Wahyuni, S. D. (2016). Sehat dan Bahagia Dengan Senam Bugar Lansia. Jurnal Penjakora, 3(1), 66-77.

Wulandari, S. T., \& Marliana, Y. (2019). Senam Kebugaran Lansia 
Pengaruh Senam Bugar Terhadap Tekanan Darah Lansia dengan...

Memengaruhi Tekanan Darah Pada

Wanita Menopause. Jurnal Kesehatan

Prima, 13(1), 18. https://doi.org/

10.32807/jkp.v13i1.216 